\title{
Noise Related Rail Access Charges in Europe: Aspects of Interoperability and Competitiveness
}

\author{
Péter Bucsky ${ }^{1 *}$ \\ ${ }^{1}$ Institute of Geography and Earth Sciences, Faculty of Sciences, University of Pécs, H-7624 Pécs, Ifjúság str. 6., Hungary \\ ${ }^{*}$ Corresponding author, e-mail: peter.bucsky@gmail.com
}

Received: 25 April 2019, Accepted: 18 June 2019, Published online: 14 November 2019

\begin{abstract}
Noise reduction of rail transport in Europe is an important step toward enhancing quality of life. According to the estimation of the European Environment Agency 14 million people are affected by rail noise in the European Union. Since the 1990s numerous measures have been taken by legislators but in practice noise levels did not lowered significantly. The changing regulations and upgraded standards have direct costs on rail freight transport and it is affecting its competitiveness. Some key countries in the European rail freight transport - Germany, Switzerland, Austria and the Netherlands - have already introduced Noise Differentiated Track Access Charges (NDTAC), which makes higher noise traffic more expensive, and encourages wagon owners to invest in low noise braking systems. Railway undertakings will face higher costs either due to higher network access charges or due to higher costs of low noise braking system. The higher costs will affect the competitiveness of rail freight transport compared to other modes of transport. Furthermore, the diverse regulation of European countries will restrict the interoperability and selective funding favors local corporations and can reduce competition. The aim of this paper is to show the possible effects of the current NDTAC regulation on the European rail freight market.
\end{abstract}

\section{Keywords}

freight rail, rail brake, interoperability, subsidy

\section{Introduction}

Railway brakes of rail freight wagons have not been changed much in the latest decades. The use of iron cast brake blocks is cheap and reliable, there was no push effect for the change. For personal wagons disc brakes have become more popular, as deceleration is faster this way, and personal wagons travel at higher speed. For freight traffic it is not economical mainly due to low distances travelled (UIC, 2008). Rail is still - after road - the second most frequent source of noise in Europe according to European Environmental Agency (EEA, 2014). It is also important to mention that the number of people affected by noise greater than $55 \mathrm{~dB}$ by road traffic was estimated by EEA to $125 \mathrm{mil}-$ lion people which is far greater than 14 million by rail.

The noise protection from road freight vehicles is much less underdeveloped and there are less technically viable options for that. The main aim is to reduce railway noise by $10 \mathrm{~dB}$, which means halving noise stress in terms of human perception (European Commission, 2015b). Different sound measurement results from Austria,
Finland, Italy and Germany. These show that rail wagons are not louder than electric or diesel locomotives or coaches, the current noise reduction schemes are only focusing on the retrofitting of rail wagons, but not the personal wagons (Kalivoda et al., 2003). Environmental aspects of the noise reduction for rail vehicles has been widely discussed and researched, but economic and cost aspects have been mainly neglected. It is important to understand the possible effects, especially in CentralEastern-Europe, where these measures will have significant effects on the rail freight market.

\section{Background}

The European Union (EU) created a working group, which finalized its Green Paper in 1996 on Future Noise Policy. It concluded that $20 \%$ of the EU's population suffers from transport noise, and the economic costs of it can be yearly between $0.2 \%$ and $2 \%$ of the EU's GDP (Commission of the European Communities, 1996). Currently it is 2.8 billion 
euros per year at the lower estimate. They calculated that the costs of noise pollution of transport per 1,000 ton-km was 12.7 ECU for road and 4.5 ECU for rail.

The White Paper of the European Commission followed in 2001, its goal was the revitalization of the European rail network. Rail noise was also important: this paper stated that there should be a possibility to introduce NDTAC for rail transport (European Commission, 2001), but it was not considering the effects of higher costs on rail freight market.

The railway noise has been a problem for longer time, and multiple measures have been taken, such as building noise barriers and track absorbers, but these measures have only limited effects on a single spot. One major problem with noise barriers is that they cannot help in the case of higher houses. A push for innovation also came, as the EU passed the Environmental Noise Directive in 2002 (2002/49/EC). Noise maps and action plans had to be created by major railway lines and cities with over a quarter million inhabitants until 2008. However, the directive did not specify any noise limit values or concrete measures. This led to different approaches in the member states.

The EU introduced new technical rules for noise reduction in the Interoperability Directive 2008/57/EC (Price and Vaerst, 2016) and for newly built wagons the so called TSI (Technical Specifications for Interoperability) norms of the European Railway Agency have been changed to lower the maximum of noise levels. The TSI for new and upgraded freight wagons were introduced in 2012 (European Commission, 2012). The new standards could be only fulfilled by the use of new materials: instead of iron cast plastic materials could be used which produce less noise but the technology had to be developed as there was no market-ready solution for that. Plastic brake blocks have also disadvantages: they are less durable and cannot conduct the heat from the wheelset and therefore lower the lifespan of them too.

The composite K blocks were the first alternative solutions to iron cast brake blocks. They require higher investment costs and require higher maintenance costs than iron cast brakes. K blocks could be used mainly on new wagons only, the retrofitting of wagons already in service with this new technology was - and still is - too expensive. Research had to be conducted on LL composite blocks, which are cheaper and do not require such expensive and extensive rebuilding of brake systems of wagons equipped with iron cast braking systems. The research and development of new brakes was a lengthy process, the first two suppliers managed to achieve the full certification of UIC only in 2012 (UIC, 2017).
The idea of noise reduction of rail freight came mainly from the densely populated Rhine-Alpine region, where the rail traffic is very dense. The first country to introduce measures to actively reduce rail noise of vehicles was Switzerland. The new legislation came into force in October 2000, and the goal was to equip $90 \%$ of Swiss rail wagons with K-blocks, which has already been achieved till the end of 2016. The 6,287 wagons of the Swiss Federal Railways (SBB) were retrofitted with K-blocks with a total costs of 134 Million $\mathrm{CHF}$, per wagon 23,060 CHF (SBB, 2016). However, according to Eurostat data, $68 \%$ of rail freight traffic in the country is transit, and therefore the initiative had little impact on people affected by rail noise. Thus, Switzerland has decided to ban every wagon which is not equipped with low noise brakes from the country starting from 2020. This is practically important for German, French and Italian railway undertakings (RU), as they are using the Swiss network the most. Those RUs which have the sufficient wagon fleet and therefore are able to transport across Switzerland will attain a better market position, while others may lose market share. The introduction of Switzerland to ban "loud" wagons from the country proved to be a pull effect for neighboring countries to introduce similar measurements.

The Commission Implementing Regulation 2015/429 with the title "Setting out the modalities to be followed for the application of the charging for the cost of noise effects" enabled differentiated network access charges possible (Regulation (EC) No 429/2015). The Netherlands and Germany were the first countries to introduce to implement NDTAC, Austria followed in 2017. Germany introduced a new law in May 2017 and will ban all rail freight wagons form the country which do not have "silent" brakes from December 2020. Fines can go up to 50,000 EUR per case, which is around the half of the value of a new freight wagon.

The intention of the EU was to facilitate the retrofitting or the replacement of the rail freight wagon fleet with less noisy wagons, but a complete ban from a member state was not intended under the regulation. The European Commission has not issued an official statement on the situation yet; however, it is expected that there will be considerable pressure to change it as the regulation is heavily impacting the single market.

The retrofitting of rail wagons with low noise brakes can be achieved by two ways. The first option could be the mandatory retrofitting by a given deadline. This option would force all wagon keepers to comply with higher noise standards. However, it has a considerable disadvantage. 
It is a highly bureaucratic decision which would impose higher costs on those wagon keepers that operate their wagons with lower mileage.

The second option is a more market friendly approach. With the introduction of NDTAC wagon keepers could calculate if their mileage is high enough to turn an investment in the retrofitting of wagons with lower noise brakes into a positive business case. The different financial state of companies and the different capital and credit accessibility possibilities favor companies with better access to funding and capital.

As the railway market is highly international within the $\mathrm{EU}$, it could have been reasonably expected that NDTAC system will be introduced as a single framework within the EU. The mandatory introduction by all member states was the proposal of the European Commission in 2012 but the European Parliament and the European Council opted for a voluntary introduction mechanism (Rail Recast Directive 2012/34/EU). It had far-reaching consequences for the whole rail freight market. It is important to emphasize that even if all current legislations and incentives work as expected, the railway noise level in Europe will not decrease considerably at least until 2030 (European Commission, 2015b).

The first country to introduce NDTAC was not within the EU. In Switzerland the railway network operator SBB Infra has been applying differentiated access charges since 2000. They opted for the option of bonus payments for retrofitted wagons. At first, wagons compliant with the new TSI norms got $0.01 \mathrm{CHF} / \mathrm{axle} / \mathrm{km}$. It has been doubled to $0.02 \mathrm{CHF} / \mathrm{axle} / \mathrm{km}$ in 2013 .

In Germany, there is also another incentive. The bonus payments are divided into two parts, both are 0.005 EUR/axle/km and both are capped until December 2020 by 211 EUR/axle/year. In sum, wagon keepers can receive 1,688 EUR/wagon maximally for a 4-axle wagon. Half of the support is given by the railway authority (Eisenbahnbundesamt). Their budget is 152 million euros for 8 years between 2012 and 2020, which should be enough - with the maximum values - to finance 180.095 wagons. According to own calculations, there are 157.000 wagons in Germany, which means that they did not expect too many foreign applications.

The other half of funding is granted by DB Netze. Companies have to pay extra fees (malus) for every $\mathrm{km}$ that they travel with iron-cast brake wagons. The value of it is $3 \%$ of the charges but it will grow to $4 \%$ from 10 December 2017. This has to be paid only if at least
$90 \%$ of the wagons in the train are "loud". The system is intended to work the way that the paid malus is financing the bonus payments. The system is very concentrated: until 2017 only 10 RUs received bonus payments - the value per wagon was 212 EUR as it can be observed in Table 1. One wagon travelled 12,476 km/year on average between 2013 and 2017 and the average funding was 206 EUR/wagon in this period in Germany (DB Netze, 2019).

The Netherlands introduced its NDTAC scheme in 2008. TSI compliant wagons receive $0.04 \mathrm{EUR} / \mathrm{wagon} / \mathrm{km}$ (Blokland and Lutzenberger, 2014). The maximal funding value per freight wagon is maximized to 4,800 EUR in the funding period.

Austria started its NDTAC scheme from 10. 12. 2017. Wagons with TSI compliant brake systems receive a $0.01 \mathrm{EUR} / \mathrm{axle} / \mathrm{km}$ bonus from the paid access charges. Payments are due after the closing of the year for the RU in charge of the operation of the trains and not the wagon keepers as in every other country. The system is planned to be in place until the end of 2021 and after that most probably only TSI compliant wagons will be allowed on the Austrian network. The maximal funding value is 425 EUR/axle for the whole funding period.

A case study in 2007 calculated that for freight trains the social costs of noise are $0.89 \mathrm{EUR} / \mathrm{train} / \mathrm{km}$ (Andersson and Ögren, 2007). With 25 pcs 4 -axle wagons in one train, it equals $0.009 \mathrm{EUR} / \mathrm{axle} / \mathrm{km}$. This shows, that the higher access charges are in line with social costs. But TSI compliant brakes cause also noise, therefore the extra burden seems too high.

Currently, there is no information if other countries are planning to introduce NDTAC schemes, which means that 4 European countries, out of which only 3 are EU member states, have it in place. Even these countries have different systems, which pose additional red tape on RUs on top of the extra costs and significant problems with interoperability. It is also important to mention, that although there are several types of rail noise mitigation measures in other regions and countries, NDTAC schemes and brake noise

Table 1 Bonus payments in Germany for TSI compliant wagons per year

\begin{tabular}{ccccc}
\hline Year & $\begin{array}{c}\text { Number of } \\
\text { requests }\end{array}$ & Wagon-km & $\begin{array}{c}\text { Nr. of } \\
\text { RUs }\end{array}$ & $\begin{array}{c}\text { Sum of bonus payments } \\
\text { (million EUR) }\end{array}$ \\
\hline 2013 & 146 & 2099287 & 2 & 0.04 \\
2014 & 5388 & 81129294 & 3 & 1.47 \\
2015 & 11025 & 178326763 & 4 & 2.34 \\
2016 & 25643 & 248910963 & 6 & 4.40 \\
2017 & 36643 & 473249007 & 10 & 8.04 \\
\hline
\end{tabular}


mitigations have not been introduced elsewhere, and there is no information available that other countries would consider it (Croft and Hemsworth, 2018). Braking is just one of several causes of rail noise, and it is also not permanent, lowering braking noise will reduce the noise of freight trains just a small portion of their travel time. Other noise mitigation options for railways are rail grinding (as poor maintenance can lead to $20 \mathrm{~dB}$ higher noise), rail dumping, noise barriers (5 dB potential) (Heutschi et al., 2016).

\section{Theories of noise related pricing}

Noise from traffic is a pollution, and in line with the polluter pays principle social external costs arising from it should be covered by the transport companies which causes it. There have been several studies carried out to calculate the external costs of transport - and especially railway - noise costs which served later as a basis for the introduction of NDTAC schemes.

A Swedish study calculated the noise tariff for the short-run marginal cost for trucks $0.03 \mathrm{EUR} / \mathrm{km}$, for low noise trucks $0.01 \mathrm{EUR} / \mathrm{km}$, for rail $0.01 \mathrm{~km} /$ wagon, for wagons with K-blocks with $0.00 \mathrm{EUR} / \mathrm{km}$ (Andersson and Ögren, 2013). The costs have been calculated based on a Swedish hedonic price study, the differences of real estate prices for quieter homes. Households have been divided into healthy and not healthy categories, the social costs of traffic noise has been calculated from the difference of this two categories.

Cost estimates for transport noise can be calculated from three main factors: (1) indirect costs, like medical costs, physical or psychiatric medical treatment of effected people; (2) direct costs, like property value as a proxy; (3) prevention costs, like noise barriers (Brons et al., 2003). For 17 EU countries the total costs of transport noise has been calculated to 0.65 of the GDP, from which $87.3 \%$ is caused by road transport, $2.3 \%$ by rail passenger transport and $3.1 \%$ by rail freight transport.

For the US market a study analyzed the external costs for rail and road transport, three type of external costs have been included: accidents, pollution and noise. For road the external cost is 1.11 USD cent per ton-mile, for rail 0.24-25 USD cents per ton-mile, the external cost for noise is the same with 0.04 USD cent per ton-mile (Forkenbrock, 2001).

A handbook has been created by TU Delft for the IMPACT EU project. This reviewed 24 research papers and categorized their findings. Two main approaches have been identified: (1) bottom-up, when calculations are based on traffic flows on a particular route; (2) top-down, when costs are calculated from the willingness to accept, compensate the noise levels, typically measured with real estate prices (Maibach et al., 2007). They also categorized the noise related costs to urban, suburban and rural. This is important, as noise costs for different transport modes differ within these categories substantially.

A literature review of 15 articles from 1976 to 2012 found that only 3 of them included noise in the negative externalities (Demir et al., 2015). The study also points out that the internalization of transport externalities is complex, no single study could deliver this for all kind of transport due to very large amount of data needed. The studies analyzed for rail noise calculated with 0.0 to 0.90 EUR cents/tkm and for road from 0.02 to 2.37 EUR cents/tkm.

Not all studies find noise pollution an important part of environmental externalities of transport: a handbook on Environmental External Costs of Transport is only considering road noise and is not dealing with rail noise (Friedrich and Bickel, 2001).

\section{The structure of ownership and operation of European freight wagons}

The effectiveness of NDTAC schemes is highly influenced by the fact of higher prices and/or price reductions can be forwarded to the owners and/or keepers of railway wagons. All current NDTAC systems are organized in a way that the RUs in charge of organizing railway transport face additional charges or discounts.

The liberalization of rail freight in the EU is a lengthy process. This also means that the number of stakeholders has grown in the recent decades. Currently, the main actors in the rail freight traffic are the following:

- The company operating the transport - these are the railway undertakings (RU), either the freight companies of former state owned incumbent railways or private entities.

- The owners of the wagons - these can be the RUs themselves, or increasingly leasing companies or private holders of wagons.

- The keepers of the wagons are the companies which are in charge of the technical state of the wagons, detailed regulations are provided by the ECM (Entity in Charge of Maintenance) system, which is regulated in the Railway Safety Directive 2004/49/EC amended by the Directive 2008/110/EC.

- The infrastructure managers - usually the state authorities, managing and operating the railway infrastructure, allocating railway capacity to RUs. 
The complexity of the problem lies in the fact that wagons transported by the RUs can be either theirs, other RUs' or can belong to private owner. For the RUs it is complicated to gain information about the technical details of third party wagons. As there is no single European database, information has to be collected separately. In addition, the level of IT systems and the access to them differ between countries. Thus, in lots of cases the RU will only know what kind of wagons are in a train when it arrives at their network.

Rail traffic can be classified into 3 main categories within the EU: domestic (51\%), international (sum of exports and imports, $39 \%$ ) and transit (10\%). The percentages represent the EU average based on ton-kms according to Eurostat in 2017. We can also split traffic into block trains and single-wagon load (SWL) traffic: in the first case, the traffic is a point-to-point full train traffic, in the second RUs are collecting wagons of different customers and organize full trains themselves.

Europe-wide data is not available on SWL traffic. The latest figures of Eurostat are from 2012. It showed that SWL in the 13 key countries of the EU and Switzerland was around $27 \%$ of all traffic in ton-kms, which is a reduction by almost $50 \%$ since 2004 when the figure was between $36 \%$ (European Commission, 2015c). This way of transport is heavily endangered by any further cost growth.

For RUs in countries without local financial incentives it is much more complicated to decide about the retrofitting to "silent" brakes as most of the time these wagons will have to travel in countries where there is no financial incentive for retrofitting (Table 2). Thus, if these RUs want to operate in the NDTAC-introduced countries, they have to face higher costs as their investment can yield return only on a smaller section of their total mileage performance.

The costs are not the same for SWL traffic and block trains: the mileage performance of SWL wagons is lower, therefore, costs of retrofitting are relatively higher. If wagons will be banned from some countries in Europe, it will force logistic companies either to reload goods - making

Table 2 Estimation of effected wagons by NDTAC schemes by type of traffic and owner

\begin{tabular}{lcccc}
\hline & $\begin{array}{c}\text { Wagon } \\
\text { owner }\end{array}$ & RUs & $\begin{array}{c}\text { Leasing } \\
\text { company }\end{array}$ & $\begin{array}{c}\text { Private } \\
\text { owner }\end{array}$ \\
\hline Traffic type & & $65 \%$ & $25 \%$ & $10 \%$ \\
Domestic & $51 \%$ & $33 \%$ & $13 \%$ & $5 \%$ \\
International & $39 \%$ & $25 \%$ & $10 \%$ & $4 \%$ \\
Transit & $10 \%$ & $7 \%$ & $3 \%$ & $1 \%$ \\
\hline
\end{tabular}

the transport longer and more expensive - or pay higher price for retrofitted wagons. As SWL is already extremely cost sensitive, it has to be assumed that traffic can be lost to other types of transport - namely road.

In the case of railway transport numerous actors take part in the organization of the transport. In this highly complicated structure the NDTAC costs are complicated to calculate and allocate to transports (Fig. 1).

The currently used NDTAC systems do not take account of the complex ownership and operational structure of rail freight wagons as the access charges are paid by the operating RUs. This means that even if a railway wagon is equipped with low noise brakes, in practice the owner will not receive bonus payments from the operating RU.

To understand the possible effect of the NDTAC system it is important to understand the structure of the European rail freight wagons, but there is no comprehensive data source available. The Eurostat data includes values for most of the countries only for the incumbent RUs, and there is no data for the biggest rail market in the EU, Germany. Combining information from Eurostat, European Commission's Transport Statistical Pocketbook (European Commission, 2018), UIP Annual Report (UIP, 2017) and RUs the number of railway wagons could be calculated and it is summarized in Table 3.

The 4 countries that have NDTAC in place are home to 234 of the total 419 European RUs. Out of the total 570 thousand rail wagons, they own 231 thousand, which is $41 \%$. There is no data sources to available how many wagons the lower noise TSI standards. According to own research in Switzerland all wagons of SBB have been retrofitted. In Germany it is expected that DB Cargo will retrofit

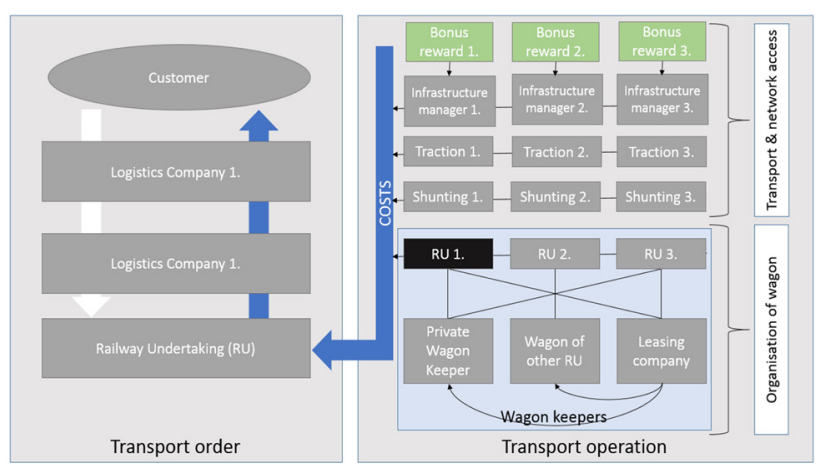

Fig. 1 The simplified structure of wagon and transport cost distribution of international transport and NDTAC schemes

Table 3 The number of rail freight wagons in the EU and Switzerland

\begin{tabular}{lcc}
\hline Railway Undertakings & Private Keepers & Total \\
\hline 350,696 & 193536 & 570216 \\
\hline
\end{tabular}


55 thousand wagons until 2020, and private owners an additional 60 thousand pieces (UIC, 2016). UIP members estimate the current new TSI and retrofitted fleet is 63 thousand, and it will grow to 132 thousand in 2020 (UIP, 2015). With estimates of incumbent railways together, the stock of TSI-compliant wagons in 2017 is around 125 thousand and it can grow to 270 thousand in 2020 .

Currently $20 \%$ of Europe's freight wagons are TSIcompliant low noise wagons, and it can grow to almost $45 \%$ by 2020 . However, the main challenge is that the half of the fleet will not, most probably, be modernized, as they are used in countries where there is no financial incentive to do so. The estimated 270 thousand silent wagons in 2020 is $17 \%$ higher than the current fleet of 230 thousand wagons of the 4 countries that introduced NDTAC. It means that the vast majority of wagons outside Germany, Switzerland, Austria and the Netherlands will not be retrofitted and the RUs of other countries will not be able to participate in the market competition on the territory of these countries, which will lead to less competition and lead to less degree of interoperability.

\section{Results}

\subsection{Costs of low noise brakes}

There is a wide range of estimations in the literature about the retrofitting costs of low noise brake systems. Furthermore, the one-off retrofitting costs are just one part of the total costs. After the one-off investment costs the ongoing maintenance costs will be also higher: life-cycle costs will grow by $16 \%$ (CER, 2017). The main reason for this is the higher cost of LL brake-casts than that of ironcast one. The composite LL brakes exert more stress on wheelsets as well. While iron-cast brakes absorb the heat of braking energy, LL composite brakes cannot do this therefore, there is more heat stress on the wheelsets. That is why there is more frequent need of monitoring wheelsets (UIP, 2015). If ss-type wagons run at speeds at $120 \mathrm{~km} / \mathrm{h}$ special monitoring is needed. K-blocks are even more expensive for retrofitting but maintenance costs are lower.

For a maximum $100 \mathrm{~km} / \mathrm{h}$ standard 4-axle wagon minimum 1250, maximum 2080 EUR for the retrofitting costs (KCW, 2011). A position paper of the European Railway Agency was calculating with 1,688 EUR (ERA, 2018.) The EU subsidized the retrofitting of 16,000 Deutsche Bahn wagons with an average cost of 1,758 EUR/wagon from CEF funds. These costs do not include the costs of re-profiling and/or changing of wheelsets. The higher maintenance costs for wagons equipped with LL-brakes will lead to cca. 300-600 EUR/wagon/year based on industry-specific estimations or at least $0.01-0.02 \mathrm{EUR} / \mathrm{km} /$ wagon. An average railway wagon rental fee is $5.000-10.000$ EUR/year depending from age and type. The higher maintenance costs are raising the wagon costs by $3-6 \%$, which is an important cost element. The additional costs will be affecting more the operators of older and cheaper wagon fleets.

\subsection{Financial impacts of retrofitting}

The market effects of the retrofitting of the European rail wagons are hard to foresee. Although the EU finds it important to shift freight traffic from road to rail, data shows that the modal split for freight is not improving, on the contrary: while share of rail in 1995 was $13.6 \%$, in 2016 it was only $17.4 \%$ for the 28 member states according to latest Eurostat data. During these two decades total traffic volume by ton-km grew by $1.1 \%$ on average annually, by rail the growth rate was only $0.3 \%$. This means rail was losing on competitiveness. The different period for retrofitting ban and subsidies leads to the loss of interoperability between countries, which will jeopardize further growth potential.

The main reasons why shippers choose road to rail are the high costs of rail transport and the less complicated organization of road transport (European Commission, 2015a). The measures for reducing the noise levels will have a factor in these two: raising costs and complicating the organization of rail transport further

From the revenue data of RUs from CER Annual Report, the revenue/wagon can be calculated (CER, 2018). If 270 thousand wagons are retrofitted at a cost of $1,500 \mathrm{EUR} /$ wagon and the yearly additional maintenance cost is 300-600 EUR/wagon, there will be a need of an additional 405 million EUR investment and the yearly total maintenance cost of wagons will be 84-168 million EUR.

Financial data is only available on company level from CER on railway corporations. These figures include also personal traffic income, which is a high portion in the case of incumbent RUs like DB, ÖBB, FS and SBB. The total yearly turnover without these corporations was 12.2 billion EUR in 2015 and with the incumbent RUs 73.3 billion EUR. The EBIDTA was 0.5 and 11.0 billion EUR respectively which is shown in Table 4 . The retrofitting costs reach $5.5 \%$ of total revenue of RUs.

For all the RUs the yearly 84 million EUR additional maintenance costs are only $0.11 \%$ of total turnover, but without the incumbent RUs it is $0.68 \%$ which is already a significant cost factor. 
Table 4 Financial data of CER Member Railway Undertakings (CER, 2018)

\begin{tabular}{lccc}
\hline & $\begin{array}{c}\text { Freight tkm } \\
\text { (millions) }\end{array}$ & $\begin{array}{c}\text { Turnover } \\
\text { (million EUR) }\end{array}$ & $\begin{array}{c}\text { EBIDTA } \\
\text { (million EUR) }\end{array}$ \\
\hline $\begin{array}{l}\sum 32 \text { CER } \\
\text { members }\end{array}$ & 458973.1 & 73307.2 & 11041.0 \\
$\begin{array}{l}\sum \text { without DB, } \\
\text { ÖBB, FS, SBB }\end{array}$ & 304506.7 & 12228.6 & 493.3 \\
\hline
\end{tabular}

\subsection{Selective funding}

RUs seated in different countries face very different financial incentives. This difference of NDTAC systems and availability of funding related to mileage has a direct market effect. Further state and EU subsidies deepen the difference. Switzerland funded the retrofitting of the SBB Cargo total fleet to K-blocks. This gave a very big advantage to the local companies as they received the new technology for free and even got the bonus from network access fees.

In Subsection 5.4 the financial impact on RUs in different countries will be analyzed. Two comparable country categories were introduced: "other close" models an RU which transports most of its international traffic through the 4 countries that introduced NDTAC schemes. It is especially the case of Central-Eastern-European countries such as Czech Republic, Slovakia, and Hungary and for instance Belgium. "Other further" is a modelled category for countries further away from the 4 countries such as Romania, Bulgaria.

The model calculation suggests that the costs of retrofitting wagons are much higher for RUs operating in third countries what can be seen from Table 5. For these companies it is financially much less viable to retrofit wagons and most probably they will not invest in it. These figures suggest that most probably the wagon fleet of Europe will be divided and the interoperability will decrease.

Table 5 Financial effects of selective funding on RUs in different countries

\begin{tabular}{lrccr}
\hline $\begin{array}{l}\text { Country of } \\
\text { RU }\end{array}$ & $\begin{array}{c}\text { Total } \\
\text { funding / } \\
\text { wagon }\end{array}$ & $\begin{array}{c}\text { Cost of } \\
\text { retro-fitting* }\end{array}$ & $\begin{array}{c}\text { Additional } \\
\text { maintenance } \\
\text { costs for } 8 \\
\text { years }\end{array}$ & Balance \\
\hline AT & 4484 & -4500 & -4800 & -4816 \\
DE & 2810 & -4500 & -4800 & -6490 \\
NL & 7440 & -4500 & -4800 & -1860 \\
CH & 31174 & -18859 & -2400 & 9915 \\
other close & 2390 & -4500 & -4800 & -6910 \\
other further & 624 & -4500 & -4800 & -8676 \\
\hline
\end{tabular}

"K-brakes in $\mathrm{CH}$ were more expensive. Price includes 1,500 EUR brake costs and 1,200 EUR for wheelsets

\subsection{Impacts on modal share}

Growing costs of wagon maintenance will have an effect on modal share. The total maintenance costs and usage of a railway wagon can be estimated to $0.07 \mathrm{EUR} / \mathrm{km}$ and a mileage of 25,000-35,000 km per year (Baumgartner, 2001). Railway transport costs can be estimated to $1.0-1.5$ EUR/wagon/km, which results to 25,000-52,500 EUR revenue per wagon per year. The additional maintenance costs of 300-600 EUR/year will result in $1.1 \%$ to $2.4 \%$ cost increase. This a cost only effecting rail transport, and no other modes of transport.

If RUs decide not to retrofit they will face higher access charges with $0.04 \mathrm{EUR} / \mathrm{km}$ for a 4 axle on average will result 1.000 to 2.100 EUR extra costs - if wagons are used only in countries with NDTAC schemes.

Price elasticity of different freight transport modes differs, the rail freight price elasticity has been estimated for $5 \%$ cost change $2 \%$ change in output measured in ton-kms (Janic, 2007). Another study found that $1 \%$ raise in rail prices effects $-1.9 \%$ in market share for rail (Jensen et al., 2019). A literature review found the price elasticity for rail mostly between $0.5 \%-1.0 \%$, but it has to be highlighted that the variation by cargo type and distance is very big (Beuthe et al., 2014).

From the above results and the expected additional costs will result the decreasing of rail transport output by $0.5 \%$ to $2.4 \%$. This would mean for the modal of rail currently by $17.3 \%$ could decrease to $16.9 \%$ to $17.2 \%$.

\subsection{Alternatives to current regulation}

The current rail noise reduction systems are not ideal, but there could have been less harmful solutions also. In the EU, according to the TSI norms of the European Railway Agency since 2011 the production of new wagons has only been allowed with low noise brakes - mainly K-blocks and to lesser extent disc brakes. As the average lifecycle of rolling stock is $25-40$ years, the substitution rate is very low. With the current pace there would be still in 2037 up to 10.000 wagons in operation with "noisy" brakes (ERA, 2018).

As wagons have to pass heavy maintenance every 6 years or after a given mileage, it could be also made compulsory to rebuild them with low noise brakes if they are under a certain age, for instance if wagons are under 25 years retrofitting could have been made mandatory in the next heavy maintenance cycle. This way the same rules could have been applied for all market players and the bulk of the wagons could have been retrofitted within 6 years. 
Alternatively, subsidies for LL-blocks could have been introduced EU-wide, this in turn would have been market-neutral, and could have helped the competitiveness of the rail industry. The management of this type of subsidy is much easier and cheaper than the complicated retrospective bonus system applied in some countries. Even a common European ban could have been more desirable for iron cast brakes. This way all market players would have been in the same situation. The change of the wagon fleet could have been speeded up by the introduction of a scrapping bonus for older and noisy wagons.

\section{Conclusions}

The incentive to lower rail freight noise in the EU will lead to retrofitting most of the continent's rail wagons to new standards on a longer term. As there is no common regulation for the whole EU, most probably the wagons in the countries that introduced NDTAC schemes will be retrofitted, while in countries outside this block not. The currently interoperable wagon fleet will be divided into two halves. This will make international transport between these two blocks more complicated and more expensive and will reduce market competition.

\section{References}

Andersson, H., Ögren, M. (2007) "Noise charges in railway infrastructure: A pricing schedule based on the marginal cost principle", Transport Policy, 14(3), pp. 204-213.

https://doi.org/10.1016/j.tranpol.2007.01.002

Andersson, H., Ögren, M. (2013) "Charging the Polluters: A Pricing Model for Road and Railway Noise", Journal of Transport Economics and Policy (JTEP), 47(3), pp. 313-333. [online] Available at: https://www. ingentaconnect.com/content/1se/jtep/2013/00000047/00000003/ art00001\#Refs [Accessed: 05 March 2019]

Baumgartner, J. P. (2001) "Prices and costs in the railway sector", Laboratoire d'Intermodalité des Transports et de Planification, Lausanne, Switzerland. [online] Available at: http://litep.epfl.ch/ webdav/site/litep/shared/Baumgartner_Couts_chf_2001_e.pdf [Accessed: 14 June 2019] (in French)

Beuthe, M., Jourquin, B., Urbain, N. (2014) "Estimating Freight Transport Price Elasticity in Multi-mode Studies: A Review and Additional Results from a Multimodal Network Model", Transport Reviews, 34(5), pp. 626-644. https://doi.org/10.1080/01441647.2014.946459

van Blokland, G., Lutzenberger, S. (2014) "Measures on Rail Traffic Noise in Europe Input paper for the Interest Group on Traffic Noise Abatement", M+P Consulting engineers BV, Vught, The Netherlands, Rep. M+P.BAFU.12.1.2.v4. [online] Available at: https:/www.mp.nl/sites/all/files/publicaties/BAFU1201\%201\%20 IGNA \%20progres\%20report \%20 on \%20railway $\% 20$ noise $\% 20$ abatement_v4.pdf [Accessed: 24 February 2019]
Railway undertakings in countries with stricter noise regulations and differentiated network access charges will join a market protection, whereas companies outside of this block will lose businesses most probably in the markets of the countries with higher NDTAC costs. On the other hand corporations which have retrofitted wagons in the 4 countries with NDTAC schemes will be less interested to use their wagons in countries where there is no financial incentive for the use of the silent brakes. This process was even more accelerated by the EU, which only gave funding for the biggest market players for the retrofitting. Selective regulation and funding in the case of an international business was not efficient to achieve lower noise levels from rail transport. Parallel to the scrapping of old wagons and investment in new ones this effect will phase out, but as the lead time of rail wagons can be measured in decades, this will have a considerable market effect at least till the end of the 2020s. The cost effect of NDTAC schemes will be considerable and as these costs will effect only rail transport it can be assumed that the modal share of this environmentally least harmful mode of transport will shrink by sensible extent.

Brons, M., Nijkamp, P., Pels, E., Rietveld, P. (2003) "Railroad noise: Economic valuation and policy", Transportation Research Part D: Transport and Environment, 8(3), pp. 169-184. https://doi.org/10.1016/S1361-9209(02)00048-2

CER (2018) "Annual Report 2017", [online] Available at: http://www.cer. be/publications/latest-publications/annual-report-2017 [Accessed: 15 March 2018]

Commission of the European Communities (1996) "Future Noise Policy - European Commission Green Paper", [online] Available at: http:/edz.bib.uni-mannheim.de/www-edz/pdf/kom/gruenbuch/ kom-1996-0540-en.pdf [Accessed: 05 December 2018]

Croft, B. E., Hemsworth, B. (2018) "State of the Art Review of Rail Noise Policy", In: Anderson, D., Gautier, P. E., Iida, M., Nelson, J. T., Thompson, D. J., Tielkes, T., Towers, D. A., de Vos, P., Nielsen, J. C. O. (eds) Noise and Vibration Mitigation for Rail Transportation Systems, In: Proceedings of the 12th International Workshop on Railway Noise, Terrigal, Australia, pp. 99-119. https://doi.org/10.1007/978-3-319-73411-8_6

DB Netze (2019) "Noise related access charges system" (Das Lärmabhängige Trassenpreissystem (LaTPS) - der Bonus für Eisenbahnverkehrsunternehmen (EVU)), [online] Available at: https://fahrweg.dbnetze.com/resource/blob/1359428/ f565959390e8616f9b4d9f00be4b9703/bonus_latps-data.pdf [Accessed: 04 April 2019] (in German)

Demir, E., Huang, Y., Scholts, S., Van Woensel, T. (2015) "A selected review on the negative externalities of the freight transportation: Modeling and pricing", Transportation Research Part E: Logistics and Transportation Review, 77, pp. 95-114.

https://doi.org/10.1016/j.tre.2015.02.020 
EEA (2014) "Noise in Europe", European Environment Agency, Copenhagen, Denmark, [online] Available at: https://www.eea. europa.eu/publications/noise-in-europe-2014/at_download/file [Accessed: 11 February 2019]

ERA (2018) "Full Impact Assessment - Revision of the Noise TSI: Application of NOI TSI requirements to existing freight wagons", [online] Available at: https://www.era.europa.eu/sites/default/files/ library/docs/recommendation/006rec1072_full_impact_assessment_en.pdf [Accessed: 27 March 2019]

European Commission (2001) "White Paper - European transport policy for 2010: time to decide", Brussels, Belgium, [online] Available at: https://ec.europa.eu/transport/sites/transport/files/themes/ strategies/doc/2001_white_paper/lb_com_2001_0370_en.pdf [Accessed: 03 January 2019]

European Commission (2012) "Towards A Comprehensive Noise Strategy", Brussels, Belgium, [online] Available at: http://www. europarl.europa.eu/RegData/etudes/etudes/join/2012/492459/IPOLENVI_ET(2012)492459_EN.pdf [Accessed: 11 February 2019]

European Commission (2015a) "Freight on road: why EU shippers prefer truck to train", Brussels, Belgium, [online] Available at: http:// www.europarl.europa.eu/RegData/etudes/STUD/2015/540338/ IPOL_STU(2015)540338_EN.pdf [Accessed: 17 February 2019]

European Commission (2015b) "Commission Staff Working Document, Rail freight noise reduction", Brussels, Belgium, [online] Available at: https://ec.europa.eu/transport/sites/transport/files/modes/rail/ doc/2016-01-05-cswc-rail-noise-reduction.pdf [Accessed: 14 February 2019]

European Commission (2015c) "Study on Single Wagonload Traffic in Europe - challenges, prospects and policy options", Brussels, Belgium, [online] Available at: https://ec.europa.eu/transport/sites/ transport/files/2015-07-swl-final-report.pdf [Accessed: 22 February 2019]

European Commission (2018) "Statistical Pocketbook 2018 - EU Transport in Figures", Brussels, Belgium. [online]. Available at: https://ec.europa.eu/transport/facts-fundings/statistics/pocketbook-2018_en [Accessed: 22 February 2019]

Forkenbrock, D. J. (2001) "Comparison of external costs of rail and truck freight transportation", Transportation Research Part A: Policy and Practice, 35(4), pp. 321-337.

https://doi.org/10.1016/S0965-8564(99)00061-0

Friedrich, R., Bickel, P. (2001) "Emission Calculation", In: Friedrich, R., Bickel, P. (eds.) Environmental External Costs of Transport, Springer, Berlin, Heidelberg, Germany, pp. 11-19.

Heutschi, K., Bühlmann, E., Oertli, J. (2016) "Options for reducing noise from roads and railway lines", Transportation Research Part A: Policy and Practice, 94, pp. 308-322. https://doi.org/10.1016/j.tra.2016.09.019

Janic, M. (2007) "Modelling the full costs of an intermodal and road freight transport network", Transportation Research Part D: Transport and Environment, 12(1), pp. 33-44. https://doi.org/10.1016/j.trd.2006.10.004

Jensen, A. F., Thorhauge, M., de Jong, G., Rich, J., Dekker, T., Johnson, D., Cabral, M. O., Bates, J., Nielsen, O. A. (2019) "A disaggregate freight transport chain choice model for Europe", Transportation Research Part E: Logistics and Transportation Review, 121, pp. 43-62. https://doi.org/10.1016/J.TRE.2018.10.004
Kalivoda, M., Danneskiold-Samsøe, U., Krüger, F., Barsikow, B. (2003) "EURailNoise: a study of European priorities and strategies for railway noise abatement", Journal of Sound and Vibration, 267(3), pp. 387-396.

https://doi.org/10.1016/S0022-460X(03)00701-6

KCW (2011) "Study to Determine the Transaction Costs of Different Incentive Models for Retrofitting the Freight Wagon Fleet with Composite Brake Blocks", KCW GmbH, Berlin, Germany, [online] Available at: http://uic.org/IMG/pdf/transaction_cost_study_ kcw_english.pdf [Accessed: 08 March 2019]

Maibach, M., Schreyer, C., Sutter, D., van Essen, H. P., Boon, B. H., Smokers, R., Schroten, A., Doll, C., Pawlowska, B., Bak, M. (2007) "Handbook on estimation of external cost in the transport sector", CE Delft, Delft, Netherlands, [online] Available at: https:// transportpublic.org/images/pdf/20080425-eurovineta/02-eng.pdf [Accessed: 13 June 2019]

Price, M., Vaerst, M. (2016) "The NDTAC scheme: Assessing the ROI and incentive for retrofitting rail freight wagons as a result of noise abatement strategies", European Railway Review, (22)6, pp. 4-8. [online] Available at: http://www.erfarail.eu/uploads/20161201_ NDTAC_Impact_on_return_of_investment_for_retrofitting_of railway_wagons.pdf [Accessed: 11 February 2019]

Regulation (EC) No 429/2015 setting out the modalities to be followed for the application of the charging for the cost of noise effects, [online] Available at: https://eur-lex.europa.eu/legal-content/EN/ TXT/HTML/?uri=CELEX:32015R0429\&from=EN [Accessed: 07 February 2019]

SBB (2016) "Lärmsanieung Basel" (Noise abatement Basel), [online] Available at: https://company.sbb.ch/content/dam/ sbb/de/pdf/sbb-konzern/ueber-die-sbb/umwelt/Standbericht_ Laermsanierung_Nr32.pdf [Accessed: 03 January 2019]

UIC (2008) "A 2007 report on the state of the art Noise Reduction in Rail Freight", [online] Available at: https://uic.org/IMG/pdf/uic-fret-en. pdf [Accessed: 09 February 2019]

UIC (2016) "Railway Noise in Europe 2016 - State of the art report. Paris: International union of railways", [online] Available at: https://uic.org/IMG/pdf/railway_noise_in_europe_2016_final.pdf [Accessed: 17 February 2019]

UIC (2017) "Brakes with composite brake blocks - General conditions for the certification of composite brake blocks", [online] Available at: https://uic.org/IMG/pdf/en541x4_m_04_2017.pdf [Accessed: 09 February 2019]

UIP (2015) "Noise - technical and operational aspects to be considered when retrofitting existing freight cars with LL brake blocks", [online] Available at: http://www.uiprail.org/index.php/files/168/ Studies\&Reports/164/20150923-Interoperability---UIP-technicalnote-on-operational-aspects-of-using-LL-brake-blocks_V1.pdf [Accessed: 09 February 2019]

UIP (2017) "Annual Report 2016. International Union of Wagon Keepers", [online] Available at: http://www.uiprail.org/index.php/ publi/annual-report/461-uip-67th-annual-report-2016 [Accessed: 09 February 2019] 